American Journal of Applied Sciences 5 (12): 1707-1712, 2008

ISSN 1546-9239

(C) 2008 Science Publications

\title{
Geochemistry of Sediment in the Major Estuarine Mangrove Forest of Terengganu Region, Malaysia
}

\author{
${ }^{1}$ B.Y. Kamaruzzaman, ${ }^{2}$ M.C. Ong, ${ }^{2}$ M.S. Noor Azhar, \\ ${ }^{1}$ S. Shahbudin and ${ }^{1}$ K.C.A. Jalal \\ ${ }^{1}$ Institute of Oceanography and Maritime Studies, \\ International Islamic University Malaysia, 25200 Kuantan, Pahang, Malaysia \\ ${ }^{2}$ Institute of Oceanography, Universiti Malaysia Terengganu, \\ 21030 Kuala Terengganu, Terengganu, Malaysia
}

\begin{abstract}
Surface sediments collected from seven estuarine mangrove forests of Terengganu region (100 sampling points) were anaylzed for $\mathrm{Pb}, \mathrm{Cu}$ and $\mathrm{Zn}$ using the sensitive Inductively Coupled Plasma Mass Spectrometer (ICP-MS). The average concentration of $\mathrm{Pb}, \mathrm{Cu}$ and $\mathrm{Zn}$ were $10.5 \pm 7.12 \mu \mathrm{g} \mathrm{g}^{-1}$ dry weights, $31.1 \pm 16.5 \mu \mathrm{g} \mathrm{g}^{-1}$ dry weights and $20.8 \pm 13.3 \mu \mathrm{g} \mathrm{g}^{-1}$ dry weights, respectively. The statistical analysis of Pearson correlation matrix has proved that there is a significant relationship between the metal concentration and the grain size. The concentration of $\mathrm{Pb}, \mathrm{Cu}$ and $\mathrm{Zn}$ decreased with the decrease of mean size particle, suggesting their association with the fine fraction of the sediments. In this study, Enrichment Factors (EF) were calculated to assess whether the concentrations observed represent background or contaminated levels. The analysis suggests that all studied elements were considered to be dominantly terrigenous in origin. Data obtained also provides a scientific discovery and data for a better understanding and proper management of the mangrove forests of Terengganu.
\end{abstract}

Key words: Surface sediment, lead, copper, zinc, mangrove forest, enrichment factor

\section{INTRODUCTION}

Mangrove sediments are anaerobic and reduced, as well as being rich in sulphide and organic matter. They therefore favour the retention of water-borne heavy metals ${ }^{[1,2]}$ and the subsequent oxidation of sulphides between tides allows metal mobilization and bioavailability ${ }^{[3]}$. Many mangrove ecosystems are close to urban development areas ${ }^{[2,4,5]}$ and are impacted by urban and industrial run-off, which contains trace and heavy metals in the dissolved or particulate form. Heavy metals are amongst the most serious pollutants within the natural environment due to their toxicity, persistence and bioaccumulation problems ${ }^{[6]}$. Due to their inherent physical and chemical properties, mangrove muds have an extraordinary capacity to accumulate materials discharged to the near shore marine environment ${ }^{[7]}$.

Recently, reclamation of mangrove ecosystems for industrial, urban and other forms of development has been increasing and it causes irreversible damage in coastal regions throughout the tropics. Along with the destruction of the mangroves come the anthropogenic effects associated with the new developments. The sediments from mangrove areas contain a historical record of information on the temporal changes that have been brought about as a result of these actions. This record is altered or smeared by the effects of sediment mixing, which influences the preservation of the physical sedimentary structures ${ }^{[8]}$. However, the alteration of the record depends on the intensity, depth and nature of the sediment mixing as well as the sediment accumulation rate. Sediment mixing also alters the biogenic components and pore water concentrations of dissolved chemical species within the sediment mixed layer ${ }^{[9,10]}$. In addition, Yingst and Rhoads ${ }^{[11]}$ documented that microbial activities are influenced by sediment mixing rates.

In Malaysia, studies relating to mangroves are not well documented and only little information is known concerning the sedimentation of the mangrove forest $^{[12,13]}$. Furthermore, geochemical studies of sediments from the Malaysian mangrove forests have received little attention and only limited studies have been done regarding their role in the process of

Corresponding Author: B.Y. Kamaruzzaman, Institute of Oceanography and Maritime Studies,

International Islamic University Malaysia, 25200 Kuantan, Pahang, Malaysia

1707 
sedimentation $^{[14]}$. In view of the importance of the mangrove to various aspects of the environment, research on the concentration of heavy metals as well as their distribution pattern in sediment was carried out.

\section{MATERIALS AND METHODS}

Sampling sites: This research was carried out at the major estuarine mangrove forest in Terengganu region. Seven major mangrove forests had been selected in this study (Fig. 1). These mangroves include the Kemaman and Chukai mangrove (KM and CK), Kerteh (KR) mangrove, Paka mangrove (PK), Dungun mangrove (DG), Marang mangrove (MR) and Setiu Mangrove (ST). The study areas lie in the wet tropics where high rainfall is recorded during the monsoon season. The northeastern monsoon prevails between the month of November and March, while the rest of the year is the transition and southwestern monsoon periods. The transects line with no physical signs of active bioturbation were selected, thus avoiding the complication of biological disturbance. Surface sediment for trace metals at all sampling points along each transect were collected by gently scraping the sediment surface.

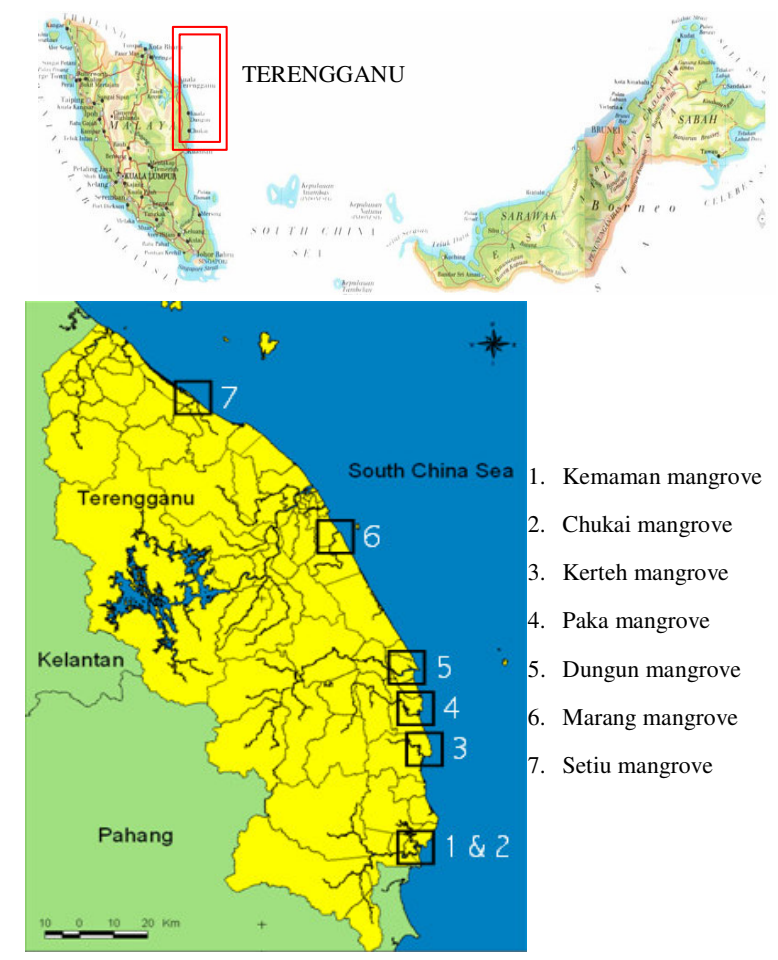

Fig. 1: Study area at 7 major estuarine mangrove area in Terengganu, Malaysia

\section{ANALYTICAL METHOD}

Analytical methods for metals: The sediment sample were digested and the analyses for total $\mathrm{Pb}, \mathrm{Cu}$ and $\mathrm{Zn}$ following the published methodologies with some modifications ${ }^{[15,16]}$. An inductively-coupled plasma mass spectrometer (ICP-MS) was used, for the quick and precise determination of $\mathrm{Pb}, \mathrm{Cu}$ and $\mathrm{Zn}$ in the digested sediment. The digestion method involved heating of $50 \mathrm{mg}$ of a finely powdered sample in a sealed Teflon vessel in a mixture with a mixed acid solution $(1.5 \mathrm{~mL})$ of concentrated $\mathrm{HF}, \mathrm{HNO}_{3}$ and $\mathrm{HCl}$. The Teflon vessel was kept at $150^{\circ} \mathrm{C}$ for $5 \mathrm{~h}$. After cooling, a mixed solution of boric acid and EDTA $(3 \mathrm{~mL})$ was added and the vessel was again heated at $150^{\circ} \mathrm{C}$ for $5 \mathrm{~h}$. After cooling at room temperature, the content of the vessel was transferred into a $10 \mathrm{~mL}$ polypropylene test tube and was dilute to $10 \mathrm{~mL}$ with deionized water. A clear solution with no residue should be obtained at the last stage. The precision assessed by the replicate analyses was less than $3 \%$. The accuracy was also examined by analyzing duplicate a Canadian Certified Reference Materials Project standard and the result coincided with the certified values within a different of $\pm 3 \%$.

Sediment characteristics analysis method: For the sediment characteristics analysis, surface sediment at all sampling points along each transect were collected during low tides. Collection was done by gently scraping the surface about 1-2 mm thickness. As sedimentological patterns relate to inorganic components of sediment, the organic components were first removed by adding $20 \%$ hydrogen peroxide $\left(\mathrm{H}_{2} \mathrm{O}_{2}\right)$ solution to the samples. The floc of finer particles were destroyed by adding a dispersing agent (5\% calgon solution). Sediments collected composed of mostly ( $80 \%$ by weight) fine sediments, while is still within the detection limit of the laser diffraction machine. Thus, sediment grain size was analyzed using the laser diffraction method only. The grain size is expressed in phi $(\phi)$ units defined by $\phi=-\log _{2} \mathrm{~d}$ where $\mathrm{d}$ is a diameter of grain in $\mathrm{mm}$. The mean, standard deviation and skewness of each sample were calculated by the moments method using equations defined by McBride $^{[17]}$. The method of moments uses data from every grain plot data to obtain statistical information concerning the sedimentary population.

\section{RESULTS AND DISCUSSION}

In this study, the concentration of all elements was found to have relatively higher values near the front mangroves. This phenomenon was also reported by 
Kamaruzzaman et al. ${ }^{[18]}$ in the Kemaman mangroves. In the front mangrove areas, enormous amounts of fine sediments are transported by the river, increasing the adsorbing surface of trace metals. Kamaruzzaman et $a l .{ }^{[18]}$ also reported that there is a positive correlation between grain size and the concentrations of $\mathrm{Cu}, \mathrm{Zn}$ and $\mathrm{Pb}$, suggesting the influence of the fine fraction in their incorporation into the sediments. The silt clay type of sediment near the riverside or the front mangroves which are rich in organic content ${ }^{[19]}$ have higher cation exchange capacities and larger surface areas ${ }^{[20]}$. Fine sediments are able to trap metal rich sediment, while sandy type sediments, organically poor sediments have little ability to retain metal ions. Figure 2 shows the plotted graph of selected element concentrations against particle mean size. However, in this study only $\mathrm{Mn}$ and $\mathrm{Pb}$ showed a significant correlation with the particle size, meanwhile the correlation of $\mathrm{Zn}$ and $\mathrm{Cu}$ were not well formed with slightly lower R-values.
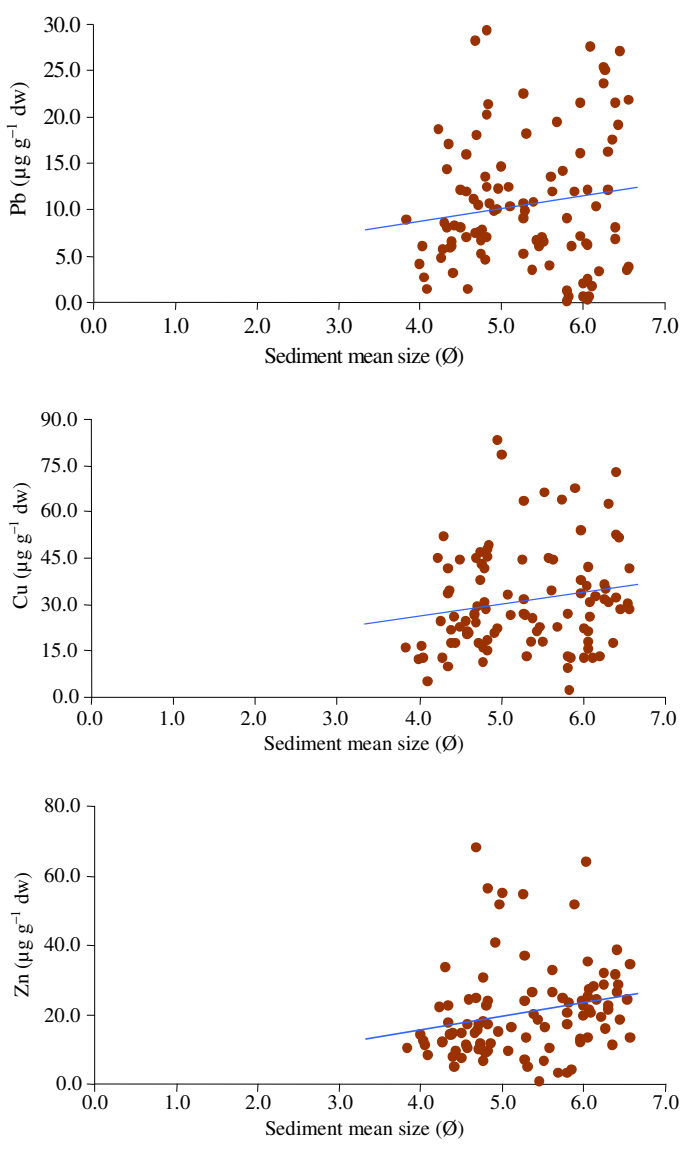

Fig. 2: Correlation between $\mathrm{Pn}, \mathrm{Cu}$ and $\mathrm{Zn}$ and sediment mean size at 7 major estuarine mangrove area in Terengganu, Malaysia
Figure 3 shows the average concentration of $\mathrm{Pb}$ in Terengganu mangrove. The $\mathrm{Pb}$ concentrations in surface sediment at Terengganu mangrove have a variable concentration. Higher concentration in some sampling station such as Paka mangrove $\left(14.17 \mu \mathrm{g} \mathrm{g}^{-1}\right.$ dry weights) may indicate that it might reflect a combination of atmospheric inputs over the mangrove with more efficient scavenging where suspended matter is higher. Setiu mangrove has the lowest $\mathrm{Pb}$ concentration with $4.61 \mu \mathrm{g} \mathrm{g}^{-1}$ dry weights). A higher concentration of $\mathrm{Pb}$ may attribute to anthropogenic input $^{[21]}$. Consequently, the use of leaded gasoline in ships and boats as well as spillage during shipment and other operations will inevitably result in higher lead levels in the environment. Other possible sources of $\mathrm{Pb}$ in Terengganu mangrove are estuarine discharge following major storm events during monsoon season, or dumping of sediments dredged. In study area, all transect located near major road (Kuala TerengganuKuantan), with heavy traffic per day may partly contribute to high levels of $\mathrm{Pb}$ observed in all sampling station. A high proportion of the $\mathrm{Pb}$ from vehicle emissions may also be transferred to the sea by way of road runoff through stormwater drains.

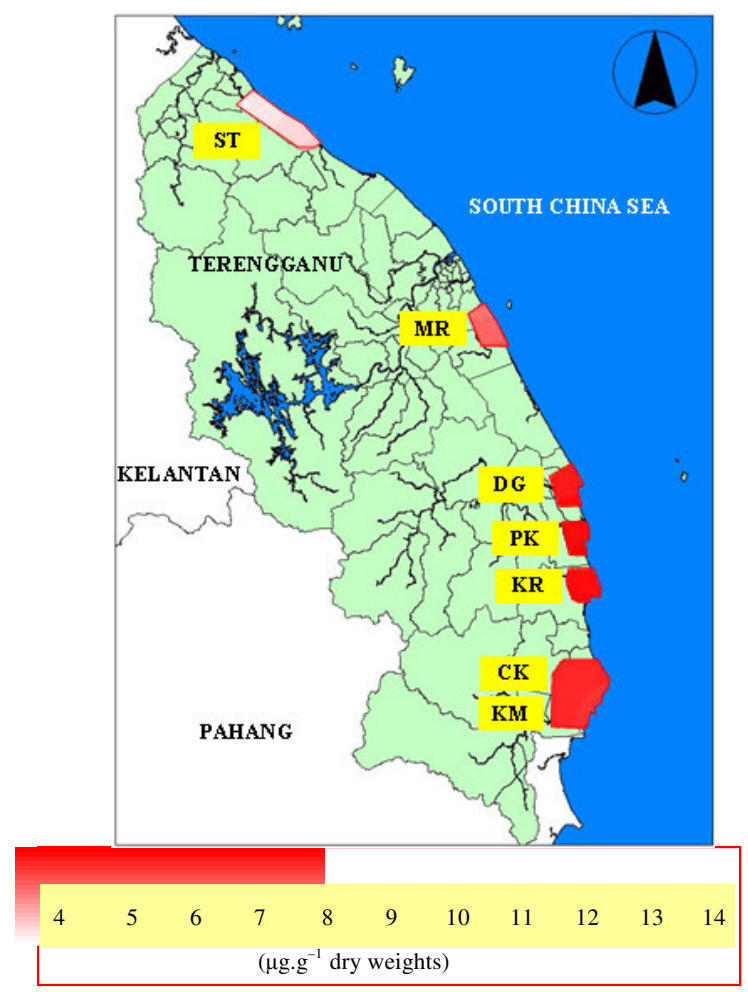

Fig. 3: $\mathrm{Pb}\left(\mu \mathrm{g} \mathrm{g}^{-1}\right.$ dry weights) distribution at 7 major estuarine mangrove area in Terengganu, Malaysia 


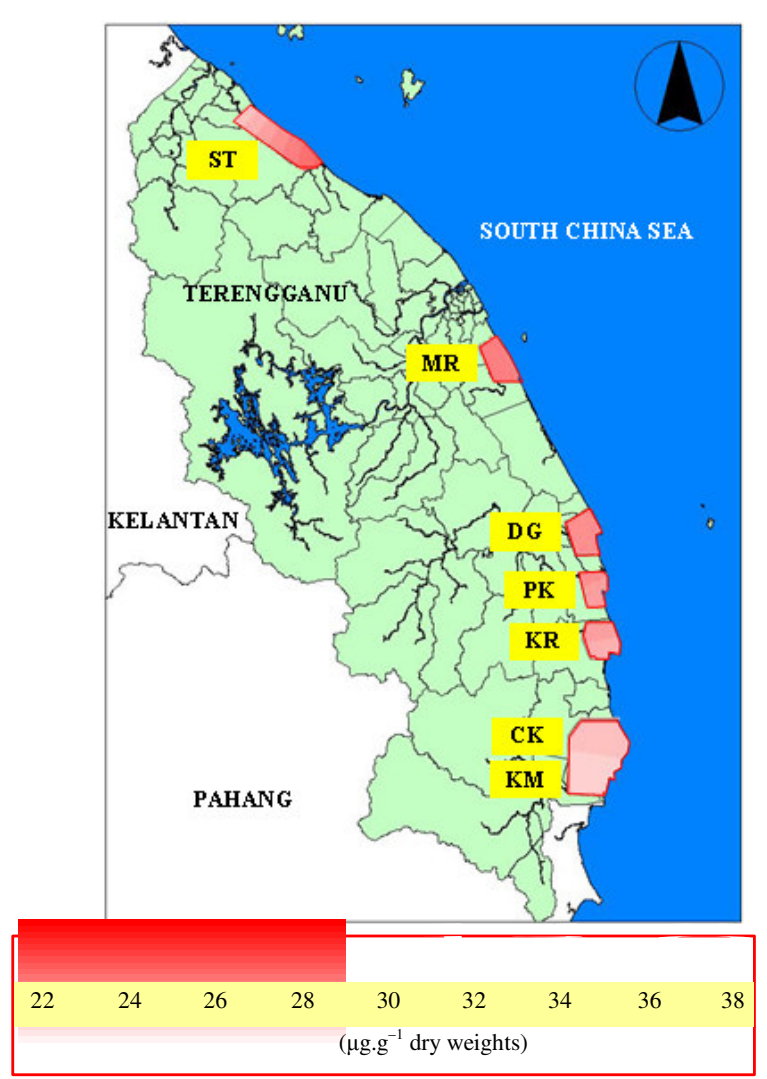

Fig. 4: $\mathrm{Cu}\left(\mu \mathrm{g} \mathrm{g}^{-1}\right.$ dry weights) distribution at 7 major estuarine mangrove area in Terengganu, Malaysia

Figure 4 shows the concentration of $\mathrm{Cu}$ at all transects in Terengganu mangrove. The highest (40.36 $\mu \mathrm{g} \mathrm{g}^{-1}$ dry weights) and lowest $\left(2.31 \mu \mathrm{g} \mathrm{g}^{-1}\right.$ dry weights) concentration of $\mathrm{Cu}$ can be obtained at Chukai mangrove and Setiu mangrove. The increased elemental concentrations in Terengganu mangrove and river system are partially attributable to port activities such as loading and offloading of fishes from fishermen, cleaning, ballasting, maintenance practices such as painting, antifouling applications, fuelling activities and oil refinery operations. For instance, $\mathrm{Cu}$ is used in electrical equipment, alloys, antifouling paint for ships' hull, as an algaecide and wood preservative ${ }^{[22]}$. It is often difficult to separate $\mathrm{Cu}$ inputs from boating sources and inputs from other sources such as urban run-off. In fact, it has been suggested that urban run-off, rather than recreational vessels, is the main source of $\mathrm{Cu}$ and other heavy metals in mooring areas. However, dynamic estuaries also experience other changes in conditions, such as tidal flushing and rainfall events, which may also influence $\mathrm{Cu}$ concentrations ${ }^{[23]}$.

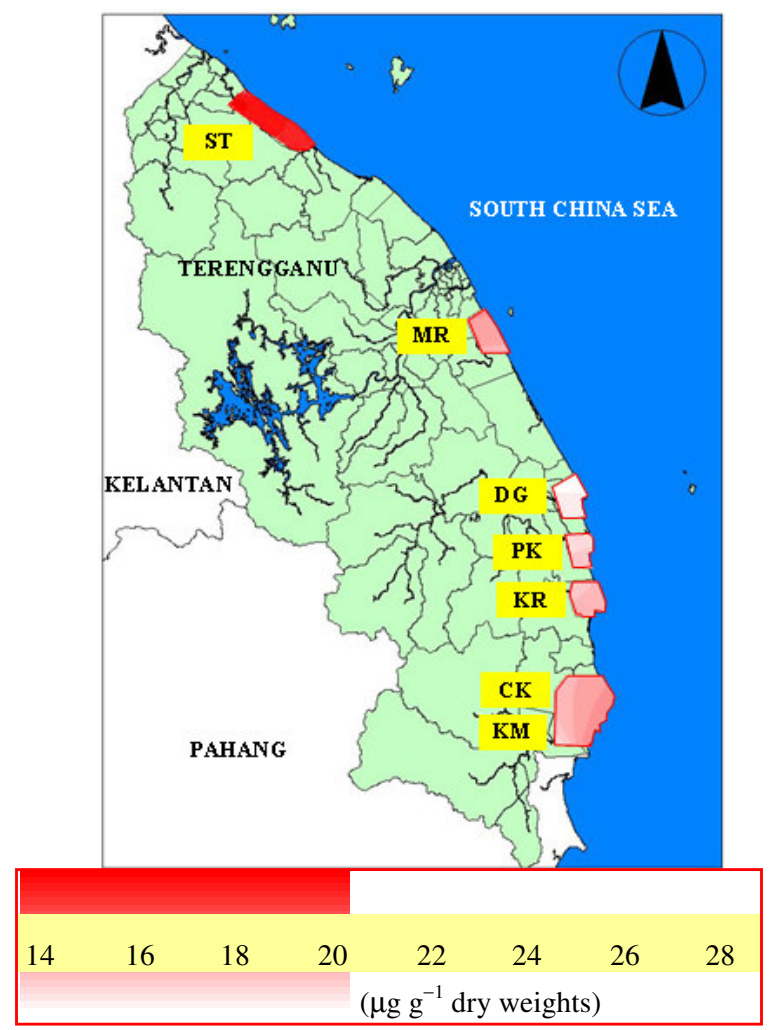

Fig. 5: $\mathrm{Zn}\left(\mu \mathrm{g} \mathrm{g}^{-1}\right.$ dry weights) distribution at 7 major estuarine mangrove area in Terengganu, Malaysia

Figure 5 shows the $\mathrm{Zn}$ concentration at all transects in Terengganu mangrove. The concentration of $\mathrm{Zn}$ in Terengganu mangrove forest was lower compared with the average shale. The concentration of $\mathrm{Zn}$ ranged from $0.83 \mu \mathrm{g} \mathrm{g}^{-1}$ dry weights to $68.2 \mu \mathrm{g} \mathrm{g}^{-1}$ dry weights with the average of $20.8 \pm 13.3 \mu \mathrm{g} \mathrm{g}^{-1}$ dry weights. From Figure, the $\mathrm{Zn}$ concentration is relatively constant for all sampling stations. In Kerteh mangrove, the concentration of $\mathrm{Zn}$ was highest while the lowest concentration of $\mathrm{Zn}$ occurs in Dungun mangrove. The source of $\mathrm{Zn}$ in study area may be due to port activities such as loading and offloading of fishes from fishermen, ballasting and antifouling applications. Besides fishing activities, the other anthropogenic sources of $\mathrm{Zn}$ in Terengganu mangrove include the mining activities, urban runoff and agricultural runoff due to the elevated $\mathrm{Zn}$ concentrations in phosphate fertilizers.

For a better estimation of anthropogenic input, an enrichment factor was calculated for each metal by dividing its ratio to the normalizing element by the same ratio found in the chosen baseline. Table 1 shows 
Table 1: EF value with respect to crustal ratios based on mean concentration determined in surface sediment in Terengganu mangrove

\begin{tabular}{lll}
\hline Element & EF value & Contamination category \\
\hline $\mathrm{Pb}$ & $1.59 \pm 0.55$ & Deficiency to minimal enrichment \\
$\mathrm{Cu}$ & $1.71 \pm 0.48$ & Deficiency to minimal enrichment \\
$\mathrm{Zn}$ & $0.88 \pm 0.37$ & Deficiency to minimal enrichment \\
\hline
\end{tabular}

the calculated EFs of the analyzed elements with respect to those determined in the crustal abundance ${ }^{[24]}$, employing the equation:

$$
\mathrm{EF}=(\mathrm{E} / \mathrm{Al})_{\text {sed }} /(\mathrm{E} / \mathrm{Al})_{\text {crust }}
$$

where, $(\mathrm{E} / \mathrm{Al})_{\text {sed }}$ and $(\mathrm{E} / \mathrm{Al})_{\text {crust }}$ are the relative concentrations of the respective element $\mathrm{E}$ and $\mathrm{Al}$ in the sediment and in the crustal material, respectively ${ }^{[25,26]}$. An enrichment factor close to 1 would indicate a crustal origin, while those with factors greater than 10 are considered to have non-crustal sources. It is clear from Table 1, all elements have values significantly about unity and are considered to be dominantly terigenous in origin. Hence, it can be suggested that the sources of heavy metal is solely natural, coming from the earth's surface that supplies particulate component to the atmosphere via the low temperature mechanical mobilization of surface deposit by wind erosion and thus incorporated into the sediment.

\section{CONCLUSION}

From the EF calculation, it is clear that concentrations of the selected elements were not greatly caused by anthropogenic activities, but moderately occurs naturally. Anthropogenic sources such as fishing activities and industrial estate may be the main reasons contributing insignificant heavy metal to the mangrove sediment. In brief, in can be concluding that there were no serious heavy metal contaminations in Terengganu mangrove forest.

\section{ACKNOWLEDGMENTS}

This research was conducted with joint funding from the Malaysia Ministry of Science Technology and Innovation under University Malaysia Terengganu Fundamental Grant 2006. The authors wish to express their gratitude to Oceanography Laboratory of both the Institute of Oceanography of UMT and Institute of Oceanography and Maritime Studies of UUIM teams for their invaluable assistance and hospitality throughout the sampling period.

\section{REFERENCES}

1. Silva, C.A.R., L.D. Lacerda and C.E. Rezende, 1990. Heavy metal reservoirs in a red mangrove forest. Biotropica, 22: 339-345.

2. Tam, N.F.Y. and W.S. Wong, 2000. Spatial variation of heavy metals in surface sediments of Hong Kong mangrove swamps. Environ. Polluti., 110: 195-205.

3. Clark, M.W., D. McConchie, D.W. Lewis and P. Saenger, 1998. Redox stratification and heavy metal partitioning in Avicennia-dominated mangrove sediments: A geochemical model. Chem. Geol., 149: 147-171.

4. MacFarlane, G.R., 2002. Leaf biochemical parameters in Avicennia marina (Forsk.) Vierh as potential biomarkers of heavy metal stress in estuarine ecosystems. Marine Pollut. Bull., 44: 244-256.

5. Preda, M. and Cox, M.E. 2002. Trace metal occurrence and distribution in sediments and mangroves, Pumicestone region, southeast Queensland, Australia. Environment International 28, 433-449.

6. MacFarlane, G.R. and M.D. Burchett, 2000. Cellular distribution of $\mathrm{Cu}, \mathrm{Pb}$ and $\mathrm{Zn}$ in the grey mangrove Avicennia marina (Forsk.) vierh. Aquat. Bot., 68: 45-59.

7. Harbison, P., 1986. Mangrove muds: A sink or source for trace metals. Marine Pollut. Bull., 17: 246-250.

8. Nittrouer, C.A., R.W. Sternberg, R. Carpenter and J.T. Bennett, 1979. The use of ${ }^{210} \mathrm{~Pb}$ geochronology as a sedimentological tool: Application to the Washington continental shelf. Marine Geol., 31: 297-316.

9. Berner, R.A., 1980. Early Diagenesis: A Theoretical Approach. Princeton University Press, Princeton, New York, pp: 241.

10. Aller, R.C., 1982. The Effects of Microbenthos on Chemical Properties of Marine Sediment and Overlying Water. In: Animal-Sediment Relations, McCall, P.L. and M.S.J. Tevesz (Eds.). Plenum Press, New York, pp: 53-102.

11. Yingst, J.Y. and D.C. Rhoads, 1980. The Role of Bioturbation in the Enhancement of Microbial Turnover Rates in Marine Sediments. In: Marine Benthic Dynamics, Tenore, K.R. and B.C. Coull (Eds). University of South Carolina Press, Columbia, pp: 407-422. 
12. Mohd Lokman, H., S. Merehojono, N.A.M. Shazili, Y. Rosnan and A.R.M. Kamil, 1994. Neap Tidal Transport of Particulate Organic Matter (POM) in a Mangrove Creek at Pulau Sekeping, Kemaman, Terengganu. In: 3rd Symposium of Applied Biology, 28-29 May, pp: 106-109.

13. Kamaruzzaman, K.Y., 1994: A Study of some Physico-Chemical Parameters in the Estuarine System of Chukai-Kemaman Rivers, Terengganu. M.Sc. Theses. Universiti Putra Malaysia, pp: 222.

14. Kamaruzzaman, K.Y., H. Suhaimi, E.K. Teh, H.F. Leong, K.H. Soon and K.Y. Chong, 2000. The determination of ${ }^{230} \mathrm{Th}$ in the sediments: Sedimentation in the mangrove Forests of Pulau Sekeping, Kemaman, Terengganu. J. Ultra Sci. Phys. Sci., 13 (2): 239-245.

15. Noriki, S.K., T. Nakanishi, M. Fukawa, T. Uematsu, H. Uchida and S. Tsunogai, 1980. Use of a Teflon vessel for the decomposition followed by determination of chemical constituents of various marine samples. Bull. Fac. Fish, Hokkaido Univ., 31: 354-465.

16. Kamaruzzaman, B.Y., 1999. Geochemistry of the Marine Sediments: Its Paleoceanographic Significance. Ph.D Thesis, Hokkaido University, Japan.

17. McBride, E.F., 1971. Mathematical Treatment of Size Distribution Data. In: Procedures in Sedimentary Petrology, Carver, R.E. (Ed.). Wiley Interscience, New York.

18. Kamaruzzaman, B.Y., N.A.M. Shazili, H. Mohd Lokman and I. Sulong, 2002. Geochemistry of some heavy metals as recorded in the sediment of the Kuala Kemaman Mangrove Forests, Terengganu, Malaysia. Oriental J. Chem., 18 (1): 7-14.
19. Waren, L.J., 1981. Contamination of sediments by lead, zinc and cadmium (A review). Environ. Pollut., 2: 401-436.

20. Horowithz, A.J. and K.A. Elrick, 1987. The relation of stream sediment surface area, grain size and composition of trace element chemistry. Applied Geochem., 2: 437-452.

21. Boutier, B., J.F. Chiffoleau, D. Auger and I. Truquet, 1993. Influence of the Loire River on dissolved lead and cadmium concentrations in coastal waters of Brittany. Estuarine Coastal and Shelf Science, 36: 133-145.

22. WHO, 1998. Copper: Environmental Health Criteria Monograph 200. International Program on Chemical Safety (IPCS). Dunn, R.J.K, 2002. Evaluation of DGT (Diffusive Gradient in Thin Films) against traditional methods for heavy metal measurements: Case studies in the Gold Coast Broadwater. Honours Thesis, Griffith University, Gold Coast.

23. Dunn, R.J.K., 2002. Evaluation of DGT (Diffusive Gradient in Thin Films) against traditional methods for heavy metal measurements: Case studies in the Gold Coast Broadwater. Honours Thesis, Griffith University, Gold Coast.

24. Taylor, S.R., 1964. Abundance of chemical elements in the continental crust: A new table Geochimica at Cosmochimica. Acta, 28: 1273-1285.

25. Molinari, E., S. Guerzoni and G. Rampazzo, 1993. Contribution of Saharan dust to the central Mediterranean Basin. Geological Soc. Am., 284: 303-312.

26. Kremling, K. and P. Streu, 1993. Saharan dust influence trace element fluxes in deep North Atlantic subtropical waters. Deep Sea Res., 40, 1155-1168. 